Grand Valley State University

ScholarWorks@GVSU

Fall 11-2002

\title{
Individual, Temporal, and Seasonal Variation in Sperm Concentration in Tree Swallows
}

\author{
Michael P. Lombardo \\ Grand Valley State University, lombardm@gvsu.edu \\ Armetris N. Forman \\ Grand Valley State University \\ Matthew R. Czarnowski \\ Rutgers University - New Brunswick/Piscataway \\ Patrick A. Thorpe \\ Grand Valley State University
}

Follow this and additional works at: https://scholarworks.gvsu.edu/biopeerpubs

Part of the Biology Commons, Fluids and Secretions Commons, Poultry or Avian Science Commons, and the Zoology Commons

\section{ScholarWorks Citation}

Lombardo, Michael P.; Forman, Armetris N.; Czarnowski, Matthew R.; and Thorpe, Patrick A., "Individual, Temporal, and Seasonal Variation in Sperm Concentration in Tree Swallows" (2002). Peer Reviewed Publications. 17.

https://scholarworks.gvsu.edu/biopeerpubs/17

This Article is brought to you for free and open access by the Biology Department at ScholarWorks@GVSU. It has been accepted for inclusion in Peer Reviewed Publications by an authorized administrator of ScholarWorks@GVSU. For more information, please contact scholarworks@gvsu.edu. 
Individual, Temporal, and Seasonal Variation in Sperm Concentration in Tree Swallows

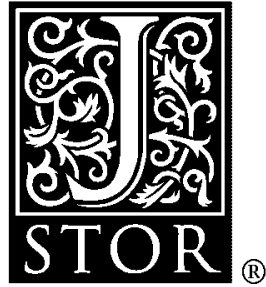

\author{
Michael P. Lombardo; Armetris N. Forman; Matthew R. Czarnowski; Patrick A. Thorpe
}

The Condor, Vol. 104, No. 4. (Nov., 2002), pp. 803-810.

Stable URL:

http://links.jstor.org/sici?sici=0010-5422\%28200211\%29104\%3A4\%3C803\%3AITASVI\%3E2.0.CO\%3B2-K

The Condor is currently published by Cooper Ornithological Society.

Your use of the JSTOR archive indicates your acceptance of JSTOR's Terms and Conditions of Use, available at http://www.jstor.org/about/terms.html. JSTOR's Terms and Conditions of Use provides, in part, that unless you have obtained prior permission, you may not download an entire issue of a journal or multiple copies of articles, and you may use content in the JSTOR archive only for your personal, non-commercial use.

Please contact the publisher regarding any further use of this work. Publisher contact information may be obtained at http://www.jstor.org/journals/cooper.html.

Each copy of any part of a JSTOR transmission must contain the same copyright notice that appears on the screen or printed page of such transmission.

JSTOR is an independent not-for-profit organization dedicated to creating and preserving a digital archive of scholarly journals. For more information regarding JSTOR, please contact support@ jstor.org. 


\title{
INDIVIDUAL, TEMPORAL, AND SEASONAL VARIATION IN SPERM CONCENTRATION IN TREE SWALLOWS
}

\author{
Michael P. Lombardo ${ }^{1,3}$, Armetris N. Forman ${ }^{1}$, Matthew R. CZarnowski ${ }^{2}$ And \\ PATRICK A. THORPE ${ }^{1}$ \\ ${ }^{1}$ Department of Biology, Grand Valley State University, Allendale, MI 49401-9403 \\ ${ }^{2}$ Department of Ecology, Evolution, and Natural Resources, Rutgers University, \\ New Brunswick, NJ 08901-2882
}

\begin{abstract}
We determined sperm concentrations in Tree Swallows (Tachycineta bicolor) by manually expressing semen samples from males during prelaying, egg-laying, incubation, and nestling periods. Sperm concentrations varied by orders of magnitude $\left(0-10^{9}\right.$ sperm $\mathrm{mL}^{-1}$ ) among males. Sperm concentrations were highest during the incubation period and lowest during the prelaying period. None of the samples collected during the prelaying, egglaying, and incubation periods were devoid of sperm. In contrast, $45 \%$ of samples collected during the nestling period lacked sperm. Sperm concentrations (1) did not vary over the course of the morning during prelaying, egg-laying, and incubation periods but significantly increased during the nestling period; (2) did not vary with the date that samples were collected during prelaying, egg laying, and incubation but significantly decreased with date during the nestling period; and (3) did not vary with the number of fertile females at the study site during any part of the breeding season. We hypothesize that the variations in sperm concentration arose from a combination of factors including intrinsic differences among males, daily patterns of sperm depletion associated with copulation, and an end-ofseason decline in sperm production. If males vary in sperm availability then female Tree Swallows may benefit from pursuing extra-pair copulations as fertility insurance.
\end{abstract}

Key words: Tree Swallow, Tachycineta bicolor, sperm concentration, sperm competition.

\section{Variación Individual, Temporal y Estacional en la Concentración de Esperma en Tachycineta bicolor}

Resumen. Determinamos la concentración de esperma en Tachycineta bicolor tomando manualmente muestras de semen de machos durante los periodos de pre-puesta, puesta de huevos, incubación y con pichones. La concentración de esperma varió en órdenes de magnitud ( $0-10^{9}$ esperma por $\mathrm{mL}$ ) entre machos. Las concentraciones de esperma fueron mayores durante el periodo de incubación y menores durante el periodo de pre-puesta. Todas las muestras colectadas durante los periodos de pre-puesta, puesta e incubación contuvieron esperma. En contraste, el $45 \%$ de las muestras colectadas durante el período con pichones no contuvieron esperma. Las concentraciones de esperma (1) no variaron durante el curso de la mañana en los periodos de pre-puesta, puesta e incubación, pero aumentaron significativamente durante el periodo con pichones; (2) no variaron con la fecha en la que las muestras fueron colectadas durante los periodos de pre-puesta, puesta e incubación, pero disminuyeron significativamente con la fecha durante el periodo con pichones; y (3) no variaron durante toda la estación reproductiva con el número de hembras fértiles en el sitio de estudio. Hipotetizamos que esta variación en la concentración de esperma se originó de una combinación de factores incluyendo diferencias intrínsecas entre machos, patrones diarios de vaciamiento de esperma asociados con la cópula, y una disminución al final de la estación en la producción de esperma. Si los machos varían en la disponibilidad de esperma, entonces las hembras de $T$. bicolor se beneficiarían de obtener copulaciones extra-pareja para asegurar la fertilidad.

\section{INTRODUCTION}

Extra-pair copulations are common in birds (Westneat et al. 1990, Birkhead and Møller

\footnotetext{
Manuscript received 7 January 2002; accepted 11 July 2002.

${ }^{3}$ E-mail: lombardm@gvsu.edu
}

1992, 1998a), setting the stage for competition between the sperm of two or more males to fertilize eggs (Parker 1970). Understanding the dynamics of sperm competition is important because it is likely to favor the evolution of male behaviors and physiological traits that maximize paternity (Birkhead and Møller 1992, 1998a). The ability to produce, store, and deliver large 
quantities of sperm are advantageous traits because they increase a male's chances of fertilizing eggs. Therefore, in species with intense sperm competition there should be strong selection pressure on males to inseminate females with large numbers of sperm cells (Parker 1970, Møller 1988, Birkhead et al. 1993). As predicted by theory, testis size, sperm counts, and ejaculate size are larger in bird species in which females copulate with several males (Castro et al. 1996, Tuttle et al. 1996, Sax and Hoi 1998).

Despite theoretically strong selection favoring sperm cell production, males vary in their expression of these traits (Birkhead and Møller 1992, 1998a, 1998b). Within species, variation among males likely results from trade-offs involving the costs of sperm production and storage (Birkhead 1998). A consequence of variation among males with evolutionary implications is differential reproductive success. Therefore, it is important to identify the sources of variation among males in these traits in order to fully understand the evolutionary dynamics of sperm competition (Birkhead and Møller 1992, 1998b). Our goal was to determine the extent of individual, temporal, and seasonal variation of sperm concentration in Tree Swallows (Tachycineta bicolor) as a first step in identifying the ultimate source of the variation in male reproductive success.

Male Tree Swallows are excellent candidates for studying variations in sperm concentrations for several reasons. First, mated Tree Swallows copulate frequently (Venier and Robertson 1991) and extra-pair copulations (EPCs) are common (Lombardo 1986, Venier et al. 1993) resulting in some of the highest recorded levels of extra-pair paternity in passerines $(50-87 \%$ of broods have extra-pair paternity; review in Barber et al. 1996). Mated male Tree Swallows provide significant amounts of paternal care (Lombardo 1991, Dunn and Hannon 1992, Winkler 1992, 1993, Lombardo et al. 1995). Surprisingly, male Tree Swallows do not closely guard their mates (Leffelaar and Robertson 1984, Chek and Robertson 1994) despite the theoretical costs of being cuckolded. The high frequencies of withinand extra-pair copulations and the lack of close mate-guarding favor a high rate of sperm production (Birkhead et al. 1993). Chek and Robertson (1994) argued that male Tree Swallows attempt to protect their paternity with frequent within-pair copulations because frequent insem- inations can improve a male's chances of fertilizing eggs (Birkhead and Møller 1992, Hunter et al. 1992, Westneat 1993a). This hypothesis predicts that male Tree Swallows should produce large numbers of sperm cells to provide for frequent inseminations while avoiding sperm depletion. Indeed, the cloacal protuberance dimensions (Lombardo 2001), testes volume (Peer et al. 2000), sperm storage tubule number and length, and sperm length of male Tree Swallows are more similar to those of some polygynandrous and polygynous birds that face intense sperm competition than they are to other monogamous birds (Briskie 1993), in concordance with this prediction. Therefore, we expected male Tree Swallow sperm concentrations to be greatest early in the breeding season when fertile females are most abundant, male chances of fertilizing eggs are the greatest, and sperm competiton is the most intense.

\section{METHODS}

We collected semen samples from male Tree Swallows that bred in wooden nest boxes mounted on metal poles erected in grids in an old field on the campus of Grand Valley State University, Ottawa County, Michigan $\left(42^{\circ} 57^{\prime} \mathrm{N}\right.$, $\left.85^{\circ} 53^{\prime} \mathrm{W}\right)$. Daily monitoring of the nest boxes began 1 May of 1999 and 2001, although some swallows returned to the study site in late March. Egg laying extended from early May to mid-June. Nests were checked daily during egg laying and eggs were numbered in sequence with indelible ink. Nests were then checked daily around the expected dates of hatching and fledging to record the length of incubation and nestling periods.

We captured swallows at their nest boxes between 07:00 and 13:00 Eastern Daylight Time during the prelaying period in 2001 and egglaying, incubation, and nestling periods in 1999. Males were identified by the presence of a cloacal protuberance, the lack of a brood patch, and plumage characteristics (Cohen 1980, 1984, Hussell 1983, Stutchbury and Robertson 1987). We banded each swallow with a U.S. Fish and Wildlife Service numbered aluminum band and gave it a unique color mark on its breast feathers with a waterproof marker to facilitate individual identification.

We manually expressed semen from males by applying gentle pressure to the seminal glomera in the cloacal protuberance (Samour et al. 1986). 
Cloacal massage may not be a reliable method for estimating natural ejaculate size (Pellatt and Birkhead 1994). However, our goal was to examine individual variation in sperm availability as estimated by sperm concentration, not to estimate ejaculate size. Furthermore, the volume of semen obtained hourly for $4 \mathrm{hr}$ from 15 males in 2001 indicated that the differences in semen volume that we obtained from males were not due to differences in our sampling effort $\left(G_{4}=\right.$ 4.2, $P>0.05$; Lombardo et al., unpubl. data).

We used sterile micropipets to collect semen samples of $1-5 \mu \mathrm{L}$ per male in whole $\mu \mathrm{L}$ volumes in 1999 and samples of $1 \mu \mathrm{L}$ per male in 2001. Trace samples (less than $0.5 \mu \mathrm{L}$ ) were not collected. Samples were immediately transferred to sterile containers containing $100 \mu \mathrm{L}$ of $5 \%$ sterile thiogylcollate broth (Troy Biologicals, Inc., Troy, Michigan) and placed on ice for transport to the laboratory. In the laboratory, each sample was mixed by vortexing on a Thermolyne MAXIMIN PLUS (BMi (Barnstead/Thermolyne, Dubuque, Iowa) for $10 \mathrm{sec}$, and $50 \mu \mathrm{L}$ was transferred into $500 \mu \mathrm{L}$ of $5 \%$ buffered formalin for sperm counting. The remaining volume was used to detect semen microbes (Lombardo and Thorpe 2000). Samples were stored at $4^{\circ} \mathrm{C}$ until counted by ANF. Three $1-\mu \mathrm{L}$ subsamples from each stored sample were individually counted using an improved Neubauer hemacytometer (Reichert, Buffalo, New York) at $1000 \times$ magnification on a compound microscope. The mean \pm SD sperm concentration (sperm $\mathrm{mL}^{-1}$ ) from each semen sample were used for comparisons among males and to investigate the relationships between sperm concentration and the date, time of day, and period in the nesting cycle when samples were collected. On each day that we collected samples we also calculated the number of fertile females at the study site. A female was categorized as fertile from six days before she laid her first egg until the day she laid her penultimate egg (Venier and Robertson 1991).

\section{STATISTICAL ANALYSES}

We used SPSS 8.0 for Windows (SPSS 1997) to examine the data for normality and used parametric and nonparametric statistical tests to analyze data where appropriate. We used the $G$ test and Fisher exact test to determine if our ability to obtain semen from males was independent of the period in the nesting cycle when
TABLE 1. Semen volumes obtained from Tree Swallows over the course of the nesting cycle. Semen volumes $<1 \mu \mathrm{L}$ were defined as trace and were not analyzed. We did not attempt to obtain volumes greater than $1 \mu \mathrm{L}$ during prelaying periods.

\begin{tabular}{lrrrrrrrr}
\hline \hline $\begin{array}{l}\text { Period in } \\
\text { nesting } \\
\text { cycle }\end{array}$ & \multicolumn{6}{c}{ Semen volume obtained $(\mu \mathrm{L})$} & \\
\cline { 2 - 8 } & 0 & Trace & 1 & 2 & 3 & 4 & 5 & Total \\
\hline Prelaying & 0 & 0 & 12 & - & - & - & - & 12 \\
Egg laying & 4 & 8 & 2 & 6 & 3 & 0 & 1 & 24 \\
Incubation & 1 & 7 & 4 & 11 & 6 & 2 & 0 & 31 \\
Nestling & 14 & 14 & 16 & 11 & 1 & 1 & 0 & 57 \\
Total & 19 & 29 & 34 & 28 & 10 & 3 & 1 & 124 \\
\hline
\end{tabular}

they were sampled. We compared sperm concentrations among periods in the nesting cycle using a Kruskal-Wallis ANOVA. We used Spearman rank correlations to detect statistically significant correlations between sperm concentration and the time in the morning, date, the number of days before a male's mate began egg laying, and number of fertile females at the study site when a male was sampled. Sequential Bonferroni corrections were used to detect statistically significant relationships during multiple comparisons (Rice 1989). We determined the repeatability of sperm concentrations obtained from males we sampled multiple times following Lessells and Boag (1987). Data are reported as means \pm SD unless otherwise stated.

\section{RESULTS}

The volume of semen we obtained from males varied among individuals and during egg-laying, incubation, and nestling periods (Table 1). The numbers of samples $\geq 1 \mu \mathrm{L}$ used to determine semen volumes and sperm concentrations differ because one sample collected during egg laying, one sample collected during incubation, and seven samples collected during nestling periods in 1999 dried out before they were counted.

Our ability to obtain semen from males was not independent of the period in the nesting cycle when males were sampled $\left(G_{3}=12.2, P<\right.$ 0.01 ). However, we were as likely to fail in obtaining semen from males while their mates were laying eggs as we were when they were tending nestlings (Table 1; Fisher exact test, $P$ $=0.56)$. We were more likely to obtain semen samples of $\geq 1 \mu \mathrm{L}$ during prelaying ( $100 \%$ of samples) and incubation (74\%) than we were during either egg laying $(50 \%)$ or the nestling period $\left(51 \% ; \chi^{2}{ }_{3}=13.7, P<0.01\right)$. 


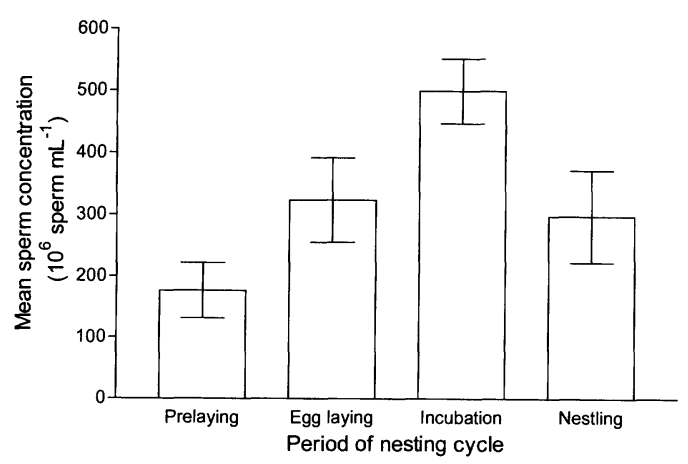

FIGURE 1. Mean ( \pm SD) sperm concentrations of Tree Swallow semen significantly varied with the period in the nesting cycle.

Sperm concentrations varied significantly over the nesting cycle (Kruskal-Wallis, $\chi_{3}^{2}=$ 13.6, $P<0.01$; Fig. 1). A Dunn's multiple comparison test revealed that sperm concentrations were significantly greater during incubation than during either the prelaying or nestling periods (both $P<0.05$ ). Furthermore, the percentage of semen samples devoid of sperm cells increased from $0 \%$ during prelaying, egg laying, and incubation to $45 \%$ (10 of 22 ) during nestling periods.

There was no relationship between mean sperm concentration and the time in the morning when we obtained semen samples during the prelaying period $\left(r_{s}=-0.24, P>0.05, n=\right.$ 12). However, mean sperm concentration decreased as the morning progressed while mates were laying eggs $\left(r_{s}=-0.66, P<0.05, n=\right.$ 11) but increased while mates were incubating eggs $\left(r_{s}=0.40, P<0.05, n=26\right)$ and tending nestlings $\left(r_{s}=0.52, P<0.05, n=22\right)$. After sequential Bonferroni corrections for multiple comparisons (Rice 1989) only the positive correlation between sperm concentration and time of day during the nestling period remained significant (Fig. 2).

Mean sperm concentrations during the prelaying period were not significantly correlated with the number of days before a male's mate began laying eggs $\left(r_{s}=0.25, P>0.05, n=12\right)$. Furthermore, mean sperm concentrations were not significantly correlated with the date that a sample was collected within the prelaying, egg-laying, and incubation periods (all $P>0.05$ ), but significantly decreased with date during the nestling period (Fig. 3, $r_{s}=-0.70, P<0.001, n$ $=22$ ).

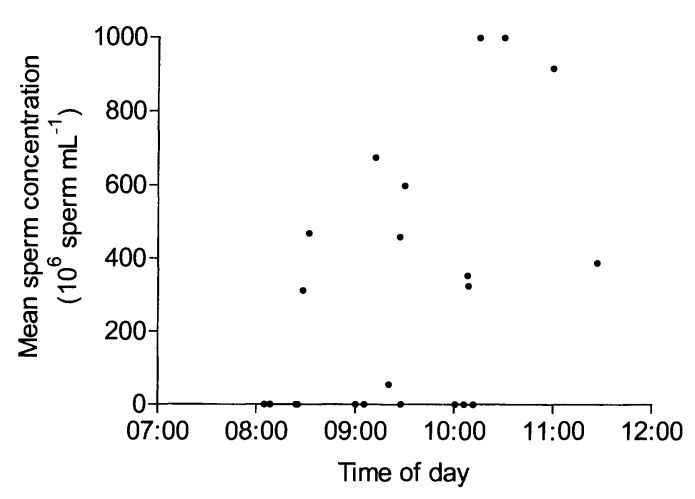

FIGURE 2. Mean sperm concentration of Tree Swallow semen significantly increased with the time of day during the nestling period.

Mean sperm concentration and the number of fertile females were not significantly correlated during the prelaying, egg-laying, and incubation periods (all $P>0.05$ ). However, mean sperm concentration was positively correlated with the number of fertile females $\left(r_{s}=0.48, P=0.02\right.$, $n=22$ ) while males were tending nestlings. After a sequential Bonferroni correction for multiple comparisons (critical value, $P=0.013$; Rice 1989) this relationship was not statistically significant.

We obtained multiple semen samples from 14 males during 1999 (Table 2). The repeatability (Lessells and Boag 1987) of sperm concentrations from two and three samples from individual males was high $(R=0.61, F=4.4, P<$ $0.05, n=14)$. Two males were sampled during egg-laying, incubation, and nestling periods. Their sperm concentrations were greatest while

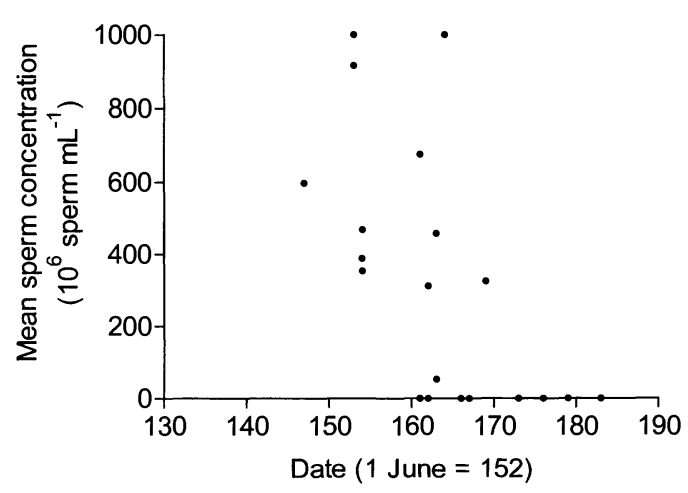

FIGURE 3. Mean sperm concentration of Tree Swallow semen significantly decreased with date during the nestling period. 
TABLE 2. Mean \pm SD sperm concentrations $\left(10^{6}\right.$ sperm $\left.\mathrm{mL}^{-1}\right)$ of male Tree Swallows sampled multiple times ( $n=3$ samples in each period) during the 1999 breeding season in Michigan.

\begin{tabular}{cccc}
\hline & \multicolumn{2}{c}{ Period in nesting cycle when sampled } \\
\cline { 2 - 4 } Male & Egg laying & Incubation & Nestling \\
\hline 16 & $58 \pm 20$ & $503 \pm 42$ & $458 \pm 89$ \\
66 & $248 \pm 142$ & $1000 \pm 66$ & 0 \\
44 & $327 \pm 25$ & $27 \pm 7$ & \\
62 & $754 \pm 117$ & $388 \pm 153$ & \\
72 & $208 \pm 142$ & $254 \pm 29$ & \\
8 & $66 \pm 13$ & & 0 \\
56 & $275 \pm 172$ & & $325 \pm 50$ \\
4 & & $254 \pm 75$ & 0 \\
23 & & $250 \pm 33$ & 0 \\
31 & & $369 \pm 32$ & $675 \pm 433$ \\
46 & & $542 \pm 46$ & $54 \pm 19$ \\
49 & & $385 \pm 25$ & 0 \\
83 & & $538 \pm 62$ & 0 \\
86 & & $756 \pm 812$ & 0 \\
\hline
\end{tabular}

their mates were incubating eggs and lowest either during the egg-laying or nestling periods. Seven males were sampled during both incubation and nestling periods but only one's sperm concentration (male 31; Table 2) was greater while he was tending nestlings than while his mate was incubating eggs. Seven of the 11 (64\%) males sampled while they were tending nestlings had sperm concentrations of 0 sperm $\mathrm{mL}^{-1}$.

\section{DISCUSSION}

Despite theoretically strong selection pressure to produce and store large numbers of sperm cells in anticipation of intense sperm competition, Tree Swallow sperm concentrations varied widely among males. Among passerines, variation in sperm counts among males or among successive ejaculates from individual males have been detected in Barn Swallows (Hirundo rustica; Møller 1994), House Sparrows (Passer domesticus; Birkhead et al. 1994), Zebra Finches (Taeniopygia guttata; Pellatt and Birkhead 1994), Dark-eyed Juncos (Junco hyemalis; Kast et al. 1998) and Red-winged Blackbirds (Agelaius phoeniceus; Westneat et al. 1998). Currently, the causes of variation in sperm production among free-ranging birds are unknown. In other species, variations in sperm production and fertility have been associated with depleted sperm supplies (Birkhead and Møller 1992, Kast et al. 1998), parasitic infections (Singer et al. 1987), reduced sperm motility (Heimann et al. 1991), and sexually transmitted diseases (Berger and Holmes 1986, Holmes et al. 1990). Regardless of its causes, individual variation in sperm production could have important reproductive consequences when sperm competition is intense because a male's probability of successfully fertilizing eggs is directly proportional to the number of his sperm relative to that of competitors (Martin et al. 1974, Birkhead and Møller 1992).

Daily patterns of copulation may also result in the variations in sperm concentration we observed among males. In passerines, sperm production occurs at night (Riley 1937, Quay 1987) and the seminal glomera are replenished before morning (Middleton 1974, Quay 1987). As a result, the number of sperm available for inseminations should decrease with successive copulations throughout the day (Middleton 1974, Riley 1937, Quay 1987). As predicted, the sperm supplies of House Sparrows (Birkhead et al. 1994) and Zebra Finches (Birkhead and Fletcher 1995) were depleted after only a few copulations and required an overnight "rest" period before replenishment. In contrast, there was no evidence of sperm depletion in Red-winged Blackbird ejaculates after copulations spaced $1 \mathrm{hr}$ apart, but sperm supplies were depleted when copulations were more closely spaced ( $\leq 10 \mathrm{~min}$; Westneat et al. 1998). This interspecific variation in sperm depletion and replenishment may reflect the different levels of sperm competition in these birds (Westneat et al. 1998). House Sparrows and Zebra Finches are primarily monogamous with relatively low frequencies of extrapair paternity (Birkhead et al. 1990, Wetton and Parkin 1991). In contrast, Red-winged Blackbirds are primarily polygynous with high frequencies of extra-pair paternity (Gibbs et al. 1990, Westneat 1993b, Gray 1996).

Low sperm concentrations in this study may have been due to depletion because some males may have ejaculated shortly before we sampled them. For example, during the egg-laying period we observed a male copulating with his mate less than $1 \mathrm{hr}$ before we unsuccessfully tried to sample him. However, we subsequently obtained a trace amount $(<1 \mu \mathrm{L})$ from him while he was tending nestlings. This observation implies that there is a lag time of uncertain length after ejaculation during which sperm supplies are depleted. Subsequent study at our study site has revealed that individual male Tree Swallows vary 
in their ability to produce consecutive semen samples when sampled hourly for $4 \mathrm{hr}$ (Lombardo et al., unpubl. data). The consequence of this lag time is that the availability of semen may influence males to prudently allocate their ejaculates between mates and extra-pair partners (Dewsbury 1982). Male Red-winged Blackbirds did not demonstrate evidence of prudent allocation of ejaculates during successive copulations with a model female fitted with a false cloaca, but the prudent allocation hypothesis was not directly tested (Westneat et al. 1998). In contrast, male Adélie Penquins (Pygoscelis adeliae) constrained by limited sperm availability strategically allocated ejaculations between their mates and extra-pair partners by withholding ejaculates from their mates (Hunter et al. 2000).

In general, sperm concentrations did not vary over the course of the morning. However, concentrations did increase as the morning progressed during the nestling period. There are at least two nonexclusive explanations for this pattern. First, during the nestling period the typical pattern of nightly sperm production and replenishment of the seminal glomera may take longer than it does earlier in the season. Second, earlymorning extra-pair copulations may not completely deplete sperm stores. Similarly, Darkeyed Junco ejaculates collected during incubation and nestling periods contained significantly more sperm than did those collected during egg laying because of a lower frequency of copulation, and consequently less sperm depletion, than that which occurred during egg laying (Kast et al. 1998).

Male Tree Swallows may have begun to limit sperm production during incubation and nestling periods in anticipation of declining opportunities for copulation. Two pieces of evidence support this hypothesis. First, semen volumes decreased with date, and $45 \%$ of the semen samples we obtained during the nestling period lacked sperm. In contrast, none of the samples obtained during the prelaying, egg-laying, or incubation periods were devoid of sperm. During prelaying, egg-laying, and incubation periods fertile extrapair females are relatively abundant, which would provide males with multiple opportunities for copulation, favoring high sperm counts (Trivers 1972). Later in the season, while males are tending nestlings, there are fewer opportunities for reproduction because fertile extra-pair females are rare. Second, the volume of the cloa- cal protuberance decreases as the season progresses and reproductive opportunities decrease (Lombardo 2001). Similarly, the reproductive organs of male Bearded Tits (Panurus biarmicus) decrease in size as the breeding season progresses and reproductive opportunities decline (Sax and Hoi 1998).

The variation among male Tree Swallows in semen volumes and sperm concentrations may help explain why female swallows frequently participate in EPCs. In a well-studied Ontario, Canada, population (Barber et al. 1996, Kempenaers et al. 1999), DNA fingerprinting revealed that in some years up to $87 \%$ of females participated in EPCs. Dunn et al. (1994) and Kempenaers et al. (1999) hypothesized that females participated in EPCs for genetic benefits such as genetic diversity and genetic compatibility, respectively. Neither directly tested the alternative hypothesis that females seek EPCs as a form of fertility insurance (Walker 1980) because they did not directly determine whether some males were either infertile or subfertile.

If individual Tree Swallow ejaculates vary in sperm concentration because of intrinsic differences between males, sperm depletion from previous copulations, or temporal and seasonal effects, then female swallows may benefit from EPCs as a form of fertility insurance. Interestingly, Tree Swallow copulatory behavior is consistent with the predictions that the fertility insurance hypothesis makes for populations in which the proportion of subfertile or infertile males is not trivial and females cannot discriminate against infertile males (Birkhead and Møller 1992): (1) A large proportion of females participate in EPCs (Kempenaers et al. 1999) and (2) most EPCs are unforced (Lombardo 1986, Venier et al. 1993). The hypothesis that female Tree Swallows may benefit from EPCs as a form of fertility insurance needs to be directly tested.

\section{ACKNOWLEDGMENTS}

We thank C. Geurink, S. Houwerzyl, J. Norris, and A. Petersen for helping to collect semen samples in 1999 and M. Green, J. Schraft, B. Sikkema, and M. Timmer for helping to collect samples in 2001. J. Briskie, D. S. Dobkin, H. Källander, A. P. Møller, H. W. Power, S. Pruett-Jones, and anonymous reviewers made helpful comments on previous versions of the manuscript. This study was supported by the Ronald E. McNair Post-Baccalaureate Achievement program award to A. N. Forman and M. P. Lombardo and by the Department of Biology at Grand Valley State University. 


\section{LITERATURE CITED}

Barber, C. A., R. J. Robertson, AND P. T. Boag. 1996. The high frequency of extra-pair paternity in Tree Swallows is not an artifact of nestboxes. Behavioral Ecology and Sociobiology 38:425-430.

Berger, R. E., AND K. K. Holmes. 1986. Infection and male infertility, p. 407-438. In R. J. Santen and R. S. Swerdlof [EDS.], Male reproductive dysfunction. Diagnosis and management of hypogonadism, infertility, and impotence. University of Washington Press, Seattle, WA.

BIRKHEAD, T. R. 1998. Sperm competition in birds: mechanisms and function, p. 579-622. In T. R. Birkhead and A. P. Møller [EDS.], Sperm competition and sexual selection. Academic Press Limited, San Diego, CA.

Birkhead, T. R., J. V. BRISKIE, AND A. P. MøLler. 1993. Male sperm reserves and copulation frequency in birds. Behavioral Ecology and Sociobiology 32:85-93.

BirkheAd, T. R., T. Burke, R. ZANN, F. M. Hunter, AND A. P. KRUPA. 1990. Extra-pair paternity and intra-specific brood parasitism in wild Zebra Finches Taeniopygia guttata, revealed by DNA fingerprinting. Behavioral Ecology and Sociobiology 27:315-324.

BirkHEAD, T. R., AND F. FletcheR. 1995. Depletion determines sperm numbers in male Zebra Finches. Animal Behaviour 49:451-456.

BIRKHEAD, T. R., AND A. P. MøLLER. 1992. Sperm competition in birds: evolutionary causes and consequences. Academic Press, New York.

BirkheAd, T. R., AND A. P. Møller [EDS]. 1998a. Sperm competition and sexual selection. Academic Press Limited, San Diego, CA.

Birkhead, T. R., AND A. P. Møller. 1998b. Sperm competition, sexual selection and different routes to fitness, p. 757-781. In T. R. Birkhead and A. P. Møller [EDS.], Sperm competition and sexual selection. Academic Press Limited, San Diego, CA.

Birkhead, T. R., J. P. Veiga, AND A. P. Møller. 1994. Male sperm reserves and copulation behaviour in the House Sparrow, Passer domesticus. Proceedings of the Royal Society of London Series B 256: 247-251.

BRISKIE, J. V. 1993. Anatomical adaptations to sperm competition in Smith's Longspur and other polygynandrous passerines. Auk 110:875-888.

Castro, I., E. O. Minot, R. A. Fordham, and T. R. BIRKHEAD. 1996. Polygynandry, face-to-face copulation and sperm competition in the Hihi Notiomystis cincta (Aves: Meliphagidae). Ibis 138: 765-771.

CheK, A. A., And R. J. Robertson. 1994. Weak mate guarding in Tree Swallows: ecological constraint or female control? Ethology 98:1-13.

CoHen, R. R. 1980. Color versus age in female Tree Swallows. Journal of the Colorado-Wyoming Academy of Science 12:44-45.

COHEN, R. R. 1984. Criteria for distinguishing breeding male Tree Swallows from brightly colored females prior to capture. North American Bird Bander 9:2-3.
Dewsbury, D. A. 1982. Ejaculate cost and male choice. American Naturalist 119:601-610.

DunN, P. O., AND S. J. HANNON. 1992. Effects of food abundance and male parental care on reproductive success and monogamy in Tree Swallows. Auk 109:488-499.

Dunn, P. O., R. J. Robertson, D. Michaud-FreEman, AND P. T. BOAG. 1994. Extra-pair paternity in Tree Swallows: why do females mate with more than one male? Behavioral Ecology and Sociobiology 35:273-281.

Gibis, H. L., P. J. Weatherhead, P. T. Boag, B. N. White, L. N. TABAK, AND D. J. HoYsaK. 1990. Realized reproductive success of polygynous Redwinged Blackbirds revealed by DNA markers. Science 250:1394-1397.

GrAY, E. M. 1996. Female control of paternity in a western population of Red-winged Blackbirds (Agelaius phoeniceus). Behavioral Ecology and Sociobiology 38:267-278.

HeimanN, P., S. LAaGe, AND H. JockusCH. 1991. Defect of sperm assembly in a neurological mutant of the mouse, wobbler (WR). Differentiation 47:77-83.

Holmes, K. K., P.-A. Mårdh, P. F. SParling, and P. J. WIESNER [EDS.]. 1990. Sexually transmitted diseases. 2nd ed. McGraw Hill, New York.

Hunter, F. M., T. BurKe, AND S. E. WatTS. 1992. Frequent copulation as a method of paternity assurance in the Northern Fulmar. Animal Behaviour 44:149-156.

Hunter, F. M., R. Harcourt, M. Wright, and L. S. DAVIS. 2000. Strategic allocation of ejaculates by male Adélie Penquins. Proceedings of the Royal Society of London Series B 267:1541-1545.

Hussell, D. J. T. 1983. Age and plumage color in female Tree Swallows. Journal of Field Ornithology 54:312-318.

Kast, T. L., E. D. Ketterson, AND V. Nolan JR. 1998. Variation in ejaculate quality in Dark-eyed Juncos according to season, stage of reproduction, and testosterone treatment. Auk 115:684-693.

Kempenaers, B., B. Cogdon, P. BoAg, And R. J. RoBERTSON. 1999. Extra-pair paternity and egg hatchability in Tree Swallows: evidence from the genetic compatibility hypothesis? Behavioral Ecology 10:304-311.

LefFelaAR, D., AND R. J. Robertson. 1984. Do male Tree Swallows guard their mates? Behavioral Ecology and Sociobiology 16:73-79.

Lessells, C. M., AND P. T. BoAg. 1987. Unrepeatable repeatabilities: a common mistake. Auk 104:116 121.

LOMBARDO, M. P. 1986. Extra-pair copulations in the Tree Swallow. Wilson Bulletin 98:150-152.

LOMBARDO, M. P. 1991. Sexual differences in parental effort during the nestling period in Tree Swallows (Tachycineta bicolor). Auk 108:393-404.

LOMBARDO, M. P. 2001. Individual and seasonal variation in the external genitalia of male Tree Swallows. Auk 118:789-795.

Lombardo, M. P., R. M. Bosman, C. A. Faro, S. G. Houtteman, AND T. S. KLuiSZA. 1995. Effect of the feathers as nest insulation on incubation behavior and reproductive performance of Tree 
Swallows (Tachycineta bicolor). Auk 112:973981.

Lombardo, M. P., And P. A. Thorpe. 2000. Microbes in Tree Swallow semen. Journal of Wildlife Diseases 36:460-468.

Martin, P. A., T. J. Reimers, J. R. Lodge, And P. J. DzIUK. 1974. The effects of ratios and numbers of spermatozoa mixed from two males on proportions of offspring. Journal of Reproduction and Fertility 39:251-258.

Middleton, A. L. A. 1974. Spermiation and sperm transport in passerine birds. Journal of Reproduction and Fertility 40:31-37.

MøLLER, A. P. 1988. Testes size, ejaculate quality, and sperm competition in birds. Biological Journal of the Linnean Society 33:273-283.

MøLler, A. P. 1994. Sexual selection and the Barn Swallow. Oxford University Press, New York.

PARKer, G. A. 1970. Sperm competition and its evolutionary consequences in the insects. Biological Reviews 45:525-567.

Pellatt, E. J., ANd T. R. Birkhead. 1994. Ejaculate size in Zebra Finches Taeniopygia guttata and a method for obtaining ejaculates from passerine birds. Ibis 136:97-106.

Peer, K., R. J. Robertson, AND B. Kempenaers. 2000. Reproductive anatomy and indices of quality in male Tree Swallows: the potential reproductive role of floaters. Auk 117:74-81.

QUAY, W. B. 1987. Spontaneous continuous release of spermatozoa and its predawn surge in male passerine birds. Gamete Research 16:83-92.

Rice, W. R. 1989. Analyzing tables of statistical tests. Evolution 43:223-225.

RILEY, G. M. 1937. Experimental studies on spermatogenesis in the House Sparrow, Passer domesticus (Linnaeus). Anatomical Record 67:327-351.

Samour, J. H., C. A. Smith, H. D. Moore, AND J. A. MARKHAM. 1986. Semen collection and spermatozoa characteristics in Budgerigars. Veterinary Record 118:397-399.

SAX, A., AND H. HoI. 1998. Individual and temporal variation in cloacal protuberance size of male Bearded Tits (Panurus biarmicus). Auk 115:964969.

Singer, R., E. Seginreich, M. Sagiv, B. Shobat, E. Livin, B. Bartoov, Z. Zuckerman, S. Leiba, AND C. SERvaIDIO. 1987. Decreased semen quality in a male infected with malaria. International Journal of Andrology 10:685-689.
SPSS. 1997. SPSS 8.0 for Windows. SPSS Inc., Chicago.

StutchbuRy, B. J., AND R. J. Robertson. 1987. Two methods of sexing adult Tree Swallows before they begin breeding. Journal of Field Ornithology 58:236-242.

Trivers, R. L. 1972. Parental investment and sexual selection, p. 136-179. In B. Campbell [ED.], Sexual selection and the descent of man 1871-1971. Aldine, Chicago.

Tuttle, E. M., S. Pruett-Jones, and M. S. Webster. 1996. Cloacal protuberances and extreme sperm production in Australian Fairy-wrens. Proceedings of the Royal Society of London Series B 263: 1359-1364.

Venier, L. A., P. O. DunN, J. T. LifJeld, AND R. J. ROBERTSON. 1993. Behavioural patterns of extrapair copulations in Tree Swallows. Animal Behaviour 45:412-415.

Venier, L. A., AND R. J. Robertson. 1991. Copulation behaviour of the Tree Swallow, Tachycineta bicolor: paternity assurance in the presence of sperm competition. Animal Behaviour 42:939948.

WALKER, W. F. 1980. Sperm utilization strategies in nonsocial insects. American Naturalist 115:780799.

Westneat, D. F. 1993a. Polygyny and extrapair fertilizations in eastern Red-winged Blackbirds (Agelaius phoeniceus). Behavioral Ecology 4:49-60.

WestneAT, D. F. 1993b. Temporal patterns of withinpair copulation, male mate-guarding, and extrapair events in eastern Red-winged Blackbirds (Agelaius phoeniceus). Behavior 124:268-290.

Westneat, D. F., L. A. McGraw, J. M. Fraterrigo, T. R. BIRKHEAD, AND F. FletChER. 1998. Patterns of courtship behavior and ejaculate characteristics in male Red-winged Blackbirds. Behavioral Ecology and Sociobiology 43:161-171.

Westneat, D. F., P. W. Sherman, and M. L. Morton. 1990. The ecology and evolution of extra-pair copulations in birds. Current Ornithology 7:331369.

WetTon, J. H., AND D. T. PARKIN. 1991. An association between fertility and cuckoldry in the House Sparrow Passer domesticus. Proceedings of the Royal Society of London Series B 245:227-233.

WINKLER, D. W. 1992. Causes and consequences of variation in parental defense behavior by Tree Swallows. Condor 94:502-520.

WINKLER, D. W. 1993. Use and importance of feathers as nest lining in Tree Swallows (Tachycineta bicolor). Auk 110:29-36. 